\title{
Högre utbildning bör ha större variation med gemensamma syften och sammanlänkad struktur: den bör sträva efter såväl akademiska som bildningsmässiga och yrkesrelaterade framsteg hos studenten
}

Den här principen bygger på tanken att det bör finnas större skillnader både inom och mellan olika utbildningsformer men att de alla bör ha gemensamma mål och värderingar. Dessa mål bör för alla omfatta utveckling av de generiska handlingsförmågorna.

\section{Om skolor för dumma och om en eftermarknad}

Visserligen måste det finnas starkt varierande utbildningsformer för olika ändamål: rörmokaren ska kunna foga samman ledningar så de inte läcker och kirurgen sy ihop kärl så de inte blöder. Men de bör alla ha det väsentligaste gemensamt: till exempel att den självständigt tänkande och handlande människan ska få stöd, stimulans och tillfälle att utveckla sig själv. Det är inte rimligt att tänka sig att det finns - mer eller mindre från födseln - olika klasser av människor där den ena ska tänka själv och utforma sina egna arbetsuppgifter medan den andra bara ska göra som hon blir tillsagd. Det är nämligen den

How to cite this book chapter:

Casson, A 2015 Högskolans ansvar: Principer för utveckling av den högre utbildningen. London: Ubiquity Press. DOI: http://dx.doi.org/10.5334/bap.k License: CC-BY 3.0 
föreställningen som alla flerdelade utbildningssystem vilar på. När jag var elva år i England på 60-talet hade jag gått i primärskolan i sex år i samma klasser som alla ungar från grannskapet, oavsett bakgrund. Några undantag fanns det nog, för dem som hade råd att betala för privatskola, men inte många, och dem kände vi för övrigt inte till. Men då, vid elvaårsåldern, delades alla barn upp i tre grupper, utifrån omfattande prov och bedömningar av akademisk framgång och fallenhet. De som skulle gå till läroverket (olika för pojkar och flickor) - the grammar school; de som skulle gå till praktiska men ändå kvalificerade yrken som krävde till exempel teknisk utbildning - the technical school; och så de övriga. De övriga skulle väl arbeta i någon fabrik eller butik eller gå som lärling, komma i tid och göra som de blev tillsagda. Fram till dess att de var gamla nog att börja med det, fick de bida tiden i någonting som med ett märkligt intetsägande namn kallades the secondary modern school. Även i Sverige och Norden fanns liknande system med realskola och folkskola. Men på 60-talet avvek Sverige från denna nästan världsomspännande uppdelningsnorm med sin enhetsskola, där uppdelningen inte skedde förrän till gymnasiet i sextonårsåldern, och då i form av ett val. Men det är ett val snävt begränsat av sedan länge inpräntade föreställningar i samhället, i familjen, hos individen om vad som är lämpligt och ett val oftast kraftigt begränsat av ett betygssystem. I Finland har man kvar sin enhetsskola; i Sverige finns numera en flora av vinstdrivande enheter som segregerat skolan på ett helt nytt och svåröverskådligt sätt.

Om man nu tror att teori och praktik inte är två av varandra oberoende fenomen och inte heller att människor är uppdelade i teoretiska och praktiska begåvningar, och att det inte heller finns en tredje grupp som inte har någon större begåvning över huvud taget, framstår en sådan uppdelning inte bara som stötande på rättvisegrunder, utan också föraktfull. Den som har ordet i sin makt har också större möjlighet att utöva makt över sitt eget och andras liv. Den som tänker klart och kan argumentera väl och vet att hitta och tolka fakta kommer troligen att få ett både längre, hälsosammare, rikare och faktiskt även lyckligare liv. Ska detta förnekas alla utom de "teoretiska begåvningarna"?

Jag menar också att i stort sett alla yrken har behov av både utvecklade praktiska färdigheter och djupare teoretiska insikter. Den snabba teknikutveckling och samhällsförändring som sker kräver att arbetskraften, eller med andra ord alla människor, är vad sociologen Manuel Castells har kallat självprogrammerande. ${ }^{160}$ Sådana människor är förmögna att själva identifiera problem och finna lösningar på dem. Behovet av monotona arbetsuppgifter i fabriker eller jordbruket eller kontor minskar i takt med automatisering och digitalisering.

160 "A major difference refers to what I call generic labor versus self-programmable labor. The critical quality in differentiating these two kinds of labor is education and the capacity of accessing higher levels of education; that is, embodied knowledge and information. The concept of education must be distinguished from skills. Skills can be quickly made obsolete by technological and organizational change. Education (as distinct from the warehousing of children and students) is the process by which people, that is labor, acquire the capability constantly to redefine the necessary skills for a given task, and to access the sources for learning these skills." (Castells 1998, s 341.) 
Varje medarbetare förväntas ingå i ett lag som tillsammans bidrar till problemlösningen. Rörmokaren kan inte bara längre kröka rör, hon måste veta varifrån energin ska komma för att värma vattnet och hur man bäst tar hand om avloppet som uppstår efter duschen. Och sedan måste hon kunna kommunicera det med sina kunder. Och hon ska kunna driva egen firma med bokföring och egna anställda och arbetsmiljöföreskrifter och hon ska sköta sin egen hemsida och, och, och. Och för detta behöver man bara gå som lärling eller öva upp greppen i en övningsverkstad?

$\mathrm{Nu}$ är förstås långt ifrån alla intresserade av att skaffa sig dessa så kallade generiska förmågor, att kunna självständigt formulera problem och självständigt identifiera verktygen och arbetssätten för att lösa dem. En del har inte intresset med sig hemifrån eller har tidigt av olika skäl tröttnat på böcker, läsning och skrivning. De har inte skaffat sig de nödvändiga redskapen att gå vidare till nästa steg. Ska vi tvinga in dem i en teoretisk utbildning? Det är så den politiska retoriken låter när den ska förklara varför det bör finnas färre högskoleplatser och flera lärlingsplatser. Men med rätt incitament, utbildningsutbud och samhällsdiskurs - det vill säga att medier och andra talar väl om högre utbildning kommer långt fler att skaffa sig lusten och förmågan att förkovra sig.

Det har också varit ett problem att utbildning har koncentrerats till en viss period under ungdomen, i stort sett avskild från samhällets arbetsliv. Nu har inslagen av praktik och arbetslivsanknytning ökat i många utbildningar, liksom återkommande vidareutbildning under hela arbetslivet. Nyligen hörde jag en högskolechef på fullt allvar kalla återkommande utbildning för "eftermarknaden", lika viktig för tjänstemannen/ingenjören som återkommande service för en lastbil. Språkbruket avslöjar att det är den nyexaminerade 22-åriga ingenjören som, liksom lastbilen, är produkten. Visserligen sägs det att den som ska bli duktig på den teoretiska matematiken borde ha klarat av det mesta av sin utveckling före 25-årsåldern för då stelnar hjärnan till, men för de flesta av oss i våra mera vardagliga yrken, borde utbildning och yrkesliv kunna integreras på ett helt annat sätt genom hela livet. Både svensk och europeisk utbildningspolitik har erkänt detta under decennier och försökt på olika sätt främja det livslånga lärandet. På senare år tycks dock möjligheterna snarare ha minskat.

Om högre utbildning ska vara tillgänglig och attraktiv för alla människor behöver det finnas en långt större variation. Högskolorna har tusentals kurser och program som täcker alla upptänkliga områden men de flesta är stöpta i samma form med enhetliga krav på poäng och examination och examensarbeten utformade efter samma mallar. Men människor med sina olika förutsättningar och förkunskaper behöver möta en rik flora av väldigt olika utbildningar som ändå har samma slutmål - självständigt tänkande, kreativa, handlingsförmögna, samarbetskunniga människor. Och därför bör också de olika delarna i systemet vara sammanlänkade. En yrkeshögskola och en högskola och ett forskningsuniversitet kan alla ha sina olika profiler och inriktningar och arbetssätt men de behöver också knytas närmare så att samma värderingar och slutmål genomsyrar alla utbildningar. Hur de mål och värderingar skulle kunna se ut, i form av handlingsförmågor, har jag visat under en tidigare princip. 


\section{Om klosterlundar och bygdehögskolor}

Om alla människor ska få stöd av den högre utbildningen i sin utveckling genom hela livet behöver den också finnas där de finns, alltså på långt flera platser än universitets- och högskoleorter. Det underlättas naturligtvis av ett brett utbud av utbildningsmöjligheter på nätet. Föreställningen att genuin akademisk kvalitet bara kan finnas där tusentals akademiker finns samlade på en plats som också varit en sådan plats i hundratals år - eller åtminstone hundra år - är nog bara ytterligare ett uttryck för den exklusivitetssträvan som präglar stora delar, inte bara av akademin utan av alla de som någon gång genomgått en akademisk utbildning på något av de gamla universiteten. Föreställningen är att de lärda samtalen bara kan pågå i vissa klosterliknande lundar. Pågår samtalen någon annanstans är de inte lärda. Hånet över bygdehögskolor bygger på ett landsortsförakt som kanske bara kan finnas i ett land där omflyttningen från land till stad har gått så snabbt och fortfarande i hög grad pågår. Visst, det tar tid att bygga en kvalitetskultur men grupper av akademiker kan ta den med sig, både till landsorten och, ännu bekvämare, till nätet.

Jag skriver om den digitala revolutionens möjligheter för högre utbildning under en annan princip. Här räcker det att säga att jag tror att man också i framtiden måste bry sig om att skapa och underhålla de fysiska miljöerna som behövs för människors utveckling genom studier. Många får en lysande utbildning på nätet och förmår utan tvekan upprätta och upprätthålla de sociala och intellektuella banden som krävs. Men jag tror att en fysisk miljö där man träffas utgör ett önskvärt och för många helt nödvändigt komplement, inte minst för motivationen. Sådana finns redan på många håll och skulle kunna utvecklas mycket tydligare i riktning mot avancerade akademiska miljöer. Jag tänker på de lärcentra som kommuner byggde upp under kunskapslyftets gyllene år men som med en förändrad politisk vilja numera försvunnit eller bytt inriktning. Jag tänker förstås också på det unikt nordiska fenomenet folkhögskolan. Ett fint namn har den redan och på många håll kvalificerade utbildningar. Men folkhögskolorna och studieförbunden skulle också kunna få en uppgift att tillsammans med högskolorna erbjuda akademiska miljöer som stöd för akademisk, bildningsinriktad och yrkesmässig utveckling.

Ett av de ständigt återkommande förmodanden som det senaste decenniets regeringars högskolepolitik bygger på är att det finns alltför många lärosäten i Sverige, och då, enligt hallonsaftsanalogin, måste kvaliteten bli utspädd. En stor volym av akademisk verksamhet måste finnas på en och samma plats för att kunna utveckla kvalitet, hävdar man, både inom och utanför akademin. Jag misstänker att också här är det exklusivitetens försvarare som är i farten. Men hur liten kan en grupp akademiker vara - givet IKT-revolutionen - för att garantera kvalitet och mångsidighet? Varför kan inte en grupp om 20 forskare i Vansbro eller Älvdalen åstadkomma storverk, både i forskningen och i undervisningen? Om en grupp med tillräckligt många vetenskapligt kompetenta, som har tillräckligt med pengar och 
goda relationer med andra lärosäten i Sverige och utomlands kan skapa en uthållig forsknings- och utbildningsmiljö på en avlägsen ort, hjälp dem att göra det. Dynamiska effekter på lokalsamhället, skolor och näringsliv kommer inte att utebli.

\section{Om anställningsbarhet och ett cirkelresonemang}

Akademiska, bildningsmässiga och yrkesrelaterade framsteg hos studenten även om de går att skilja åt som aspekter inom en utbildningsgång, bildar de tillsammans en treenighet, där varje del är eller borde vara beroende av de två andra. Det akademiska fokuserar det självständiga tänkandet och sanningssökandet, förmågan att finna och värdera fakta men också den precisa och klara formuleringskonsten. Det bildningsmässiga fokuserar individen och hennes egen utveckling, tillsammans med andra. En människas livslånga strävan att uppnå sin fulla potential, att utveckla så många av de centrala handlingsförmågorna, i Nussbaums termer, så fullödigt som möjligt, skapar en allt bättre självkännedom och stigande självaktning. Men om man överblickar de senaste årens utbildningspolitiska diskurs med alla dess policydokument, regelverk, och utvecklingsinitiativ, är det framförallt de yrkesmässiga framsteg som har stått i centrum och då i väldigt speciell bemärkelse: Anställningsbarhet. Employability.

Om en person är anställningsbar innebär det att hon besitter en uppsättning färdigheter (skills) som något företag eller organisation just vid det tillfället efterfrågar. Om du inte är anställningsbar - eller användbar, som är ett uttryck som man tagit till senare i ett misslyckat försök att bredda begreppet - måste du väl vara oanvändbar. Begreppen objektifierar studenten och gör utbildning till en ren produktionsprocess. Trots det har många inom den högre utbildningen svalt begreppen och använt dem i policydokument i ett försök att gå de finansierande makthavarna och deras opinionsbildare till mötes. Vi kanske ska vara tacksamma för att det i Sverige fortfarande finns ett utbildningsdepartement som har hand om högre utbildning. I England har högskolefrågorna de senaste tjugo åren som sagt legat under Department for Business, Innovation and Skills, alltså ett näringsdepartement med ansvar också för de färdigheter som högskolor förväntas uppöva.

Anställningsbarhet och användbarhet är begrepp som man kan misstänka är framtaget som svar på arbetsbrist i samhället, begrepp som lägger ansvaret för arbetsbristen på individen som inte är anställningsbar snarare än på politiker, arbetsgivare, en marknad, ett samhällsystem eller andra tänkbara ansvariga. Visst måste ett av den högre utbildningens viktigaste mål vara att bidra till att människor kan sköta kvalificerade arbeten, men knappast bara fylla ett hål i produktionsapparaten med en uppsättning begränsade färdigheter som behövs för stunden.

Ett genomgående argument i mitt resonemang är att utbildning inte bara - inte ens främst - är till för ekonomisk tillväxt. Men om man nu för en 
stund skulle anta att jag har fel och att tillväxt verkligen är huvudmålet, måste man åtminstone tala om vad man tror ekonomisk tillväxt, i sin tur, är till för. Om den är till för att så många som möjligt ska få ett gott liv, behöver man också ägna en del tanke åt vad som är ett gott (och kanske över tid hållbart) liv. Det är vanligt att hävda att studier eller forskning är bara berättigade om de på något sätt bidrar till ekonomin. Det är till och med så att man inte ens argumenterar för detta utan tar det för givet, som ett obestridligt faktum. Forskning i latinets böjningsmönster eller en kandidatutbildning i estetik betraktas som hobbyverksamhet som möjligen kan tolereras som en finkulturell fernissa. Det finns en opinion för att fristående kurser som inte ingår i en yrkesutbildning som leder till anställning bör avgiftsbeläggas i Sverige. Staten tar inte ansvar för den typen av utbildning, det får individen betala själv och det med full kostnadstäckning. Således kan en viss aktivitet, till exempel studier eller forskning, berättigas bara om den leder till mera pengar. Men om det goda livet som de pengarna ska leda till, inte bara består av den tillfälliga njutning som konsumtion kan ge utan också att flera människor får mera tid att ägna åt meningsfulla fritidsaktiviteter - som till exempel studier eller till och med så kvalificerade studier att de kan kallas forskning - uppstår onekligen en märklig cirkellogik: du får bara studera konst om du kan tjäna pengar på det, samtidigt som de pengar du tjänar gärna får användas till sådant som att studera konst. Stefan Collini skriver om detta på ett elegant sätt: "en hel del av den moderna diskursen befinner sig i den självmotsägande belägenheten att en viss verksamhet $\mathrm{A}$ bara är berättigad om den kan bevisas bidra till att man tjänar mera pengar, samtidigt som det erkänns att avsikten med att tjäna mera pengar är för att underlätta för oss att fortsätta göra sådana saker som verksamhet A."161

Det är orimligt att tänka sig att ett flerskiktat utbildningsystem, skapat för att tillgodose behoven i det tidiga industrisamhället, ska fortsätta upprätthållas på de ärvda privilegiernas grund. Människor har ungefär samma begåvning och talang - vad de behöver är motivation, stöd och uppmuntran med rimliga ekonomiska förutsättningar. Framtidens samhälle behöver ett sammanhängande system av högre utbildning för alla, med en bred uppsättning med sinsemellan väldigt olika institutioner, som på olika sätt fokuserar huvud, hand och hjärta. Men alla med en gemensam strävan att stödja utvecklingen av självkänslan och handlingsförmågorna som behövs för att utforma både den egna och samhällets framtid. Vad vi till stora delar redan har fått istället i Sverige är en högskola som enbart utgör en del av produktionsapparaten, en högskola som är ett företag bland alla andra, styrd av marknadens regler om konkurrens, vinstmaximering och utdelning till ägarna. Nu är det hög tid att ifrågasätta det.

161 "Much contemporary discourse finds itself in the self-defeating position of arguing that the carrying-on of activity A is justified only if it can be shown to contribute to making more money, while acknowledging that the purpose of making more money is to enable us to continue doing things such as carrying on activity A." (Collini 2012, s 110) 